Available online on 15.05.2019 at http://ujpr.org
Universal Journal of Pharmaceutical Research
An International Peer Reviewed Journal
Open access to Pharmaceutical research

\title{
SERO-EPIDEMIOLOGICAL STUDY OF HEPATITIS B, C, HIV AND TREPONEMA PALLIDUM AMONG BLOOD DONORS IN HODEIDA CITY- YEMEN \\ Ahmed Mohsen Al-kadassy ${ }^{1}{ }^{\mathbb{D}}$, Hassan Abdulwahab Al-Shamahy ${ }^{2}{ }^{\mathbb{D}}$, Abdulmalik Faisal Saleh Al-Ashiry ${ }^{1}$ (D) \\ ${ }^{I}$ Medical Microbiology, Faculty of Medicine and Health Sciences, Hodeidah University, Hodeidah city, Yemen. \\ ${ }^{2}$ Medical Microbiology and Clinical Immunology, Faculty of Medicine and Health Sciences, Sana'a University, Republic of Yemen.
}

\section{ABSTRACT}

Objective: Infections transmitted in blood transfusions are the most significant concern associated with blood donation. The purpose of this study was to establish the current prevalence of hepatitis viruses (B and C), HIV and T. pallidium among blood donors at National Blood Transfusion and Research Center (NBTRC) Hodeida Branch, Hodeida city, Yemen.

Methods: Serological markers of HBV, HCV, HIV 1, 2, T. pallidium antibodies were studied in 25446 (males) using commercially available kits, over a period of 3 years from January 2016 to April 2018 at National Blood Transfusion and Research Center (NBTRC) Hodeida Branch , Hodeida city, Yemen. Also, the prevalence of confirmed-positive test results of these infections was evaluated among different ages.

Results: The sero-prevalence of HBV, HCV, HIV, T. pallidium infections based on confirmation tests, were $0.74 \%, 0.19 \%, 0.38 \%$ and $0.18 \%$ respectively. The prevalence of HBV was significantly higher in age groups 37-46 years and 47-56 years with significant associated OR equal to $2.3(p<0.001)$ and $\mathrm{OR}=2.7(p=0.02)$ respectively. The prevalence of $\mathrm{HCV}$ was significantly higher in age groups 47-56 years with significant associated OR equal to 6.5 ( $p=0.003)$. The prevalence of T. pallidium was significantly higher in age group 37-46 years with significant associated OR equal to $3.6(p<0.001)$.

Conclusion: This study highlights the prevalence of HBV, HCV, HIV, and T. pallidium among different male ages. The prevalence varies from one age group to another, being the lowest among younger and very older age groups. Therefore, extensive recruitment of young donors should help ensure a long-term increase in the blood supply without jeopardizing safety.

Keywords: Blood donors, HBV, HCV C, HIV, Hodeida city, T. pallidium, Yemen.

Article Info: Received 1 March 2019; Revised 5 April; Accepted 8 May, Available online 15 May 2019

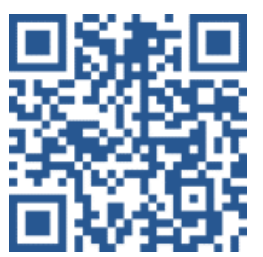

Cite this article-

Al-kadassy AM, Al-Shamahy HA, Al-Ashiry AFS. Sero-epidemiological study of hepatitis B, C, HIV and treponema pallidum among blood donors in Hodeida city- Yemen. Universal Journal of Pharmaceutical Research 2019; 4(2): 38-42.

DOI: https://doi.org/10.22270/ujpr.v4i2.256

Address for Correspondence:

Prof. Hassan A. Al-Shamahy, Faculty of Medicine and Heath Sciences, Sana'a University, P.O. Box 775 Sana'a, Yemen. Phone: +967-770299847, E-mail: shmahe@yemen.net.ye

\section{INTRODUCTION}

Blood transfusion is one of the most important tools in modern medical therapy, and saving patients is its aim. If the safe blood supply is not considered, it can be lifethreatening. However, the blood has its potential risks causing serious side effects in the recipients. It is known that bacteria, viruses and parasites can be transmitted through blood transfusions ${ }^{1,2}$. Choosing healthy donors with low risk of blood contamination is one of concerns around the world. The World Health Organization (WHO) recommends that all donated blood be tested for transfusion transmissible infections. These include HIV, Hepatitis B, Hepatitis C, Treponema pallidum (syphilis) and, where relevant, other infections that pose a risk to the safety of the blood supply, such as Trypanosoma cruzi (Chagas disease) and Plasmodium species (malaria) ${ }^{3}$.

According to the WHO, 25 countries are not able to screen all donated blood for one or more of: HIV; Hepatitis B; Hepatitis C; or syphilis. One of the main reasons for this is because testing kits are not always available. However the prevalence of transfusion-transmitted infections is much higher in low income countries compared to middle and high income countries ${ }^{4,5}$. HBV, HCV, HIV and Treponema pallidium (syphilis) infections are important causes of morbidity and mortality worldwide and pose problems in the safety of blood transfusion. Because of the 
shared modes of transmission, $\mathrm{HBV} / \mathrm{HCV} / \mathrm{HIV} / T$. pallidium co-infection is not uncommon in highly endemic areas and among subjects with a high-risk of parenteral transmission. Prolonged vascular exposure and multiple blood transfusions increase the risk of acquiring these blood-borne infections in endemic areas as Yemen. According to the Yemeni National Infectious Viral Hepatitis Control Programme, Yemen was recognized as HBV-endemic area ${ }^{6}$. In 1998 the WHO recommended the entrance of hepatitis B vaccine in the national immunization programmes of Yemen $^{7}$, particularly among neonates, where vertical transmission is common, regardless of the $\mathrm{HBsAg}$ prevalence. The incidence of acute $\mathrm{HBV}$ has declined dramatically during the past decade after the vaccination programme, especially among young individuals, although, it still may take several decades until the effect of vaccination will be translated into reduced transmission and morbidity in general. The purpose of this study was to establish the current prevalence of hepatitis viruses (B and C), HIV and $T$. pallidium among blood donors at National Blood Transfusion and Research Center (NBTRC) Hodeida Branch, Hodeida city, Yemen.

\section{SUBJECTS AND METHODS}

This was a retrospective study. The study was depending on data collection from the records of National Blood Transfusion \& Research Center (NBTRC) Hodeidah Branch, Yemen. The study data included data of three years from 1 January 2016 to $30^{\text {th }}$ of April 2018. A total of 25446 of blood donors were included in this study. They were the blood donors whom came to NBTRC for blood donation during 3 years. The donor's ages ranged from $17->56$ years with healthy normal weight (not less than $50 \mathrm{~kg}$ ). The data collected included: gender, address, blood pressure, weight, blood group, $\mathrm{Hb}$ level, the date of donation, the donation number, and the screening test results for HBV, HCV, HIV and Syphilis. Blood donation in
Yemen is depending on male donors and it is rare for female to be blood donors. Also blood donation is semi-voluntary by friends and relatives of patients but voluntary donation is not the role.

\section{Blood Testing}

The blood donors sera were tested by rapid immunochromatographic assay (RICA) kits and confirmed by ELISA test (ABON) for diagnosis of Hepatitis B surface Antigen ( $\mathrm{HBsAg}$ ), antibodies to $\mathrm{HCV}$, antibodies to HIV, and antibodies (IgG and IgM) for Treponema Pallidum (TP).

\section{Inclusion Criteria of blood donors}

Potential donors were accept for donation if they are clinically healthy individuals between 18-60 years of age, with body weight of above $45 \mathrm{Kgs}$, Hemoglobin more than $12.5 \mathrm{gm} / \mathrm{dl}$ and no significant medical or surgical history.

\section{Exclusion Criteria}

Potential donors were excluded if they were below 17 years old, weighed less than $45 \mathrm{~kg}$, had anemia and a history of jaundice within the past six months, engaged in high-risk behavior (i.e., unsafe intercourse, drug use etc), or donated blood within the past three months.

Statistical Analysis

To relate age as possible risk factor for $\mathrm{HBV}, \mathrm{HCV}$, HIV and $T$. pallidium infections, the data were examined in a case-control study format. With confirmed positive tests of $\mathrm{HBV}, \mathrm{HCV}, \mathrm{HIV}$ and $T$. pallidium were matched up with those who were HBV, HCV, HIV or T. pallidium negative. The chi square was used to see the association Odds ratios (OR) and their $95 \%$ confidence intervals (CI). Values (OR, CI, $\chi^{2}$ ) were estimated using $2 \times 2$ tables to identify possible odds ratio on occurrence of $\mathrm{HBV}, \mathrm{HCV}, \mathrm{HIV}$ or $T$. pallidium and their significance. The result at $\mathrm{p}$-value 0.05 was considered as statistically significant.

\section{Ethical Consideration}

Ethical clearance for the study was taken from the Faculty of Medicine and Health Sciences Research Review Committee.

Table 1: The prevalence of $H B V, H C V, H I V$ and $T$. pallidium among blood donors attending to National Blood Transfusion and Research Center during 3 year periods.

\begin{tabular}{|c|c|c|c|c|c|c|}
\hline \multirow[t]{2}{*}{ Infections } & \multirow[t]{2}{*}{ Years } & \multirow[t]{2}{*}{$\begin{array}{l}\text { Total } \\
\text { tested }\end{array}$} & \multicolumn{2}{|c|}{ Positive } & \multicolumn{2}{|c|}{$\begin{array}{c}\text { Total of } 3 \text { years } \\
\text { positive }\end{array}$} \\
\hline & & & No. & $\%$ & No. & $\%$ \\
\hline \multirow{3}{*}{$\mathrm{HBV}$} & 2016 & 10817 & 113 & 1.04 & 189 & 0.74 \\
\hline & 2017 & 10063 & 50 & 0.5 & & \\
\hline & 2018 & 4600 & 26 & 0.57 & & \\
\hline \multirow{3}{*}{$\mathrm{HCV}$} & 2016 & 10817 & 12 & 0.11 & 49 & 0.19 \\
\hline & 2017 & 10063 & 18 & 0.18 & & \\
\hline & 2018 & 4600 & 19 & 0.41 & & \\
\hline \multirow{3}{*}{ HIV } & 2016 & 10817 & 56 & 0.52 & 98 & 0.38 \\
\hline & 2017 & 10063 & 27 & 0.27 & & \\
\hline & 2018 & 4600 & 15 & 0.33 & & \\
\hline \multirow{3}{*}{ T. pallidium } & 2016 & 10817 & 38 & 0.35 & 45 & 0.18 \\
\hline & 2017 & 10063 & 5 & 0.05 & & \\
\hline & 2018 & 4600 & 2 & 0.04 & & \\
\hline \multirow{3}{*}{ Co-infection } & 2016 & 10817 & 2 & 0.02 & 5 & 0.02 \\
\hline & 2017 & 10063 & 1 & 0.01 & & \\
\hline & 2018 & 4600 & 2 & 0.04 & & \\
\hline Total & $\begin{array}{l}2016- \\
2018\end{array}$ & 25446 & 386 & 1.52 & 386 & 1.52 \\
\hline
\end{tabular}




\section{RESULTS}

A total number of 25446 blood donors were included in this study. The prevalence of HBV, HCV, HIV, and $T$. pallidium were $0.74 \%, 0.19 \%, 0.38 \%$, and $0.18 \%$, respectively with total prevalence of tested infectious agents equal to $1.52 \%$ (Table 1 ). When age groups of blood donors were considered, there was significant increase in $\mathrm{HBV}$ rate in age group 47-56 years $(1.94 \%$ with associated OR equal to $2.7 ; 95 \% \mathrm{CI}=1.1-6.6, \chi^{2}$
$=5.1$, and $p=0.02)$, followed by age group 37-46 years (1.44\%, OR=2.3; 95\% CI=1.6-3.1, $\chi^{2}=5.1, \quad p=0.02$. However, lower rate of HBV was found in younger age groups (Table 2). Also, a high prevalence of HCV was in age group 47-56 years $(1.2 \%)$ with associated OR equal to $6.5 ; 95 \% \mathrm{CI}=1.9-20.9, \chi^{2}=12.8$, and $p=0.003$. However, low prevalence rate of $\mathrm{HCV}$ was found in other age groups and $0 \%$ was found in age group $>56$ years (Table 3$)$.

Table 2: The prevalence and associated odds ratio of HBV for different age groups for blood donors under study in Hodeidah city-Yemen.

\begin{tabular}{|c|c|c|c|c|c|c|c|}
\hline \multirow[t]{2}{*}{ Age groups } & \multirow[t]{2}{*}{$\begin{array}{c}\text { Number } \\
\text { tested }\end{array}$} & \multicolumn{2}{|c|}{$\begin{array}{c}\text { HBV } \\
\text { positive }\end{array}$} & \multirow[t]{2}{*}{ OR } & \multirow[t]{2}{*}{ CI } & \multirow[t]{2}{*}{$\chi^{2}$} & \multirow[t]{2}{*}{$P$} \\
\hline & & No. & $\%$ & & & & \\
\hline $17-26$ years & 11393 & 86 & 0.76 & 1 & $0.7-1.3$ & 0.04 & 0.82 \\
\hline $27-36$ years & 10657 & 54 & 0.5 & 0.5 & $0.4-0.7$ & 13.7 & $<0.001$ \\
\hline $37-46$ years & 3052 & 44 & 1.44 & 2.3 & $1.6-3.1$ & 23 & $<0.001$ \\
\hline $47-56$ years & 257 & 5 & 1.94 & 2.7 & $1.1-6.6$ & 5.1 & 0.02 \\
\hline$>56$ years & 87 & 0 & 0 & \multicolumn{2}{|c|}{ undefined } & 5.1 & 0.02 \\
\hline Total & 25446 & 189 & 0.74 & & & & \\
\hline
\end{tabular}

$\mathrm{OR}=\mathrm{Odds}$ ratio $=$ Relative risk, $\mathrm{CI}=$ Confidence intervals, $\chi^{2}=$ Chi-square $=3.9$ or more significant, $p v=$ Probability value $=0.05$ or less significant

On the other hand, there was no significant variation of the prevalence of HIV among the different age groups of the blood donors; and zero prevalence of HIV was found in older age groups (47-56 years and >56 years) (Table 4). A higher prevalence of $T$. pallidium was found in age group 37-46 years $(0.49 \%)$ with associated OR equal to $3.6\left(95 \% \mathrm{CI}=1.9-6.8, \chi^{2}=19.4\right.$, $p<0.001)$. However, low rate of $T$. pallidium was found in younger age groups and $0 \%$ was found in age group $>56$ years (Table 5 ).

Table 3: The prevalence of HCV and associated odds ratio for different age groups for blood donors under study in Hodeidah city-Yemen.

\begin{tabular}{|c|c|c|c|c|c|c|c|}
\hline $\begin{array}{l}\text { Age } \\
\text { groups } \\
\text { (years) }\end{array}$ & $\begin{array}{c}\text { Number } \\
\text { tested }\end{array}$ & $\begin{array}{r}\text { HC } \\
\text { posi } \\
\text { No. } \\
\end{array}$ & $\begin{array}{l}\text { V } \\
\text { tive } \\
\% \\
\end{array}$ & OR & CI & $\chi^{2}$ & $P$ \\
\hline $17-26$ & 11393 & 27 & 0.23 & 1.5 & $0.8-2.6$ & 2.1 & 0.14 \\
\hline $27-36$ & 10657 & 15 & 0.14 & 0.1 & $0.3-1.1$ & 2.5 & 0.1 \\
\hline $37-46$ & 3052 & 4 & 0.13 & 0.6 & $0.2-1.8$ & 0.6 & 0.41 \\
\hline $47-56$ & 257 & 3 & 1.2 & 6.5 & $1.9-20.9$ & 12.8 & 0.003 \\
\hline$>56$ & 87 & 0 & 0 & \multirow{2}{*}{\multicolumn{2}{|c|}{ undefined }} & 0.6 & 0.40 \\
\hline Total & 25446 & 49 & 0.19 & & & & \\
\hline
\end{tabular}

$\mathrm{OR}=$ Odds ratio $=$ Relative risk, $\mathrm{CI}=$ Confidence intervals, $\chi^{2}=$ Chi-square $=3.9$ or more significant, $p v=$ Probability value $=0.05$ or less significan

\section{DISCUSSION}

The prevalence of $\mathrm{HBV}(0.74 \%)$ and $\mathrm{HCV}(0.19 \%)$ in the current study are lower than previously reported in Yemen $(4-20 \%, 1.5 \% \text { respectively })^{8}$. The differences in the prevalence between our study and previous studies in Yemen may be attributed to differences in the sensitivities of the assays used, the criteria of positivity, types of donors as well as in the degree to which individuals with risk factors for blood-borne viral infections may have been excluded. In most of the earlier studies, an earlier generation of anti-HCV ELISA (which was less sensitive and less specific) was used. However, in our study a fourth generation ELISA was used for confirmation, which was more sensitive and more specific. In general, the prevalence of hepatitis $\mathrm{B}$ and $\mathrm{C}$ were lower among young donors than older donors in the current study.

Table 4: The prevalence of HIV and associated odds ratio for different age groups for blood donors attending to National Blood Transfusion and Research Center during 3 year periods.

\begin{tabular}{|c|c|c|c|c|c|c|c|}
\hline $\begin{array}{l}\text { Age groups } \\
\text { (years }\end{array}$ & $\begin{array}{c}\text { Number } \\
\text { tested }\end{array}$ & $\begin{array}{r}\text { HI } \\
\text { posit } \\
\text { No. }\end{array}$ & $\begin{array}{l}\text { ive } \\
\% \\
\end{array}$ & OR & CI & $\chi^{2}$ & $P$ \\
\hline $17-26$ & 11393 & 47 & 0.41 & 1.1 & $0.7-1.6$ & 0.4 & 0.51 \\
\hline $27-36$ & 10657 & 35 & 0.32 & 0.7 & $0.5-1.1$ & 1.7 & 0.19 \\
\hline $37-46$ & 3052 & 16 & 0.52 & 1.4 & $0.83-2.4$ & 1.7 & 0.18 \\
\hline $47-56$ & 257 & 0 & 0 & \multicolumn{4}{|c|}{ Undefined } \\
\hline$>56$ & 87 & 0 & 0 & \multicolumn{4}{|c|}{ Undefined } \\
\hline Total & 25446 & 98 & 0.38 & & & & \\
\hline
\end{tabular}

$\mathrm{OR}=$ Odds ratio $=$ Relative risk, $\mathrm{CI}=$ Confidence intervals, $\chi^{2}=$ Chi-square $=3.9$ or more significant, $P=$ Probability value $=0.05$ or less significant 
This confirm the results reported earlier by other investigators $^{9,10}$ this may be explained on the basis of increased exposure with age and on the fact that a high awareness of blood-borne viral infections has developed and a comprehensive vaccination program against hepatitis B has been implemented in Yemen. It should be noted that the carrier rate of $\mathrm{HBV}$ was higher than the carrier rate of $\mathrm{HCV}$ in this study and in other studies $^{8-12}$. These data suggested that the mode of transmission and the efficiency of transmission of HBV may be different from that of HCV. Also, the prevalence of HCV among Yemeni donors was shown to be relatively low $(0.19 \%)$, this was in an agreement with other studies carried in USA $(0.29 \%)^{13}$, Central America $(0.19 \%)^{14}$, Germany $(0.1 \%)^{15}$, Australia $(0.29 \%)^{16}$, Singapore $(0.37 \%)^{17}$ and Iran $(0.09 \%)^{18}$. This can be explained by an introduction of newer generation of anti-HCV testing in BT service has contributed to control and reduction of transmission of $\mathrm{HCV}$ as this virus is primarily parenterally transmitted. Human immunodeficiency virus infection is a major health problem in sub-Saharan Africa where the prevalence of HIV among blood donors ranges between $2-20 \%$ in $\operatorname{Kenya}^{19}$ and $5.9 \%$ in Ethiopia ${ }^{20}$. However, our results showed low level of unconfirmed HIV in the analyzed donors $(0.38 \%)$. Thus, in our study the prevalence of HIV in Yemen was recorded as $0.1 \%$ among blood donors and other studies have reported the lower than our results ${ }^{21}$ this can be explained on the basis that Yemen is an Islamic country where religious culture and traditions are practiced, as Islamic rules prohibit extramarital sexual activities and drug abuse, in addition to screening of expatriates workers entering the Yemen and increased educational awareness have contributed to the success of HIV control in Yemen.

Table 5: The prevalence of $T$. pallidium, and associated odds ratio for different age groups for blood donors under study.

\begin{tabular}{|c|c|c|c|c|c|c|c|}
\hline \multirow[t]{2}{*}{$\begin{array}{l}\text { Age groups } \\
\text { (years }\end{array}$} & \multirow[t]{2}{*}{$\begin{array}{c}\text { Number } \\
\text { tested }\end{array}$} & \multicolumn{2}{|c|}{$\begin{array}{l}\text { T. pallidium } \\
\text { positive }\end{array}$} & \multirow[t]{2}{*}{ OR } & \multirow[t]{2}{*}{$C I$} & \multirow[t]{2}{*}{$\chi^{2}$} & \multirow[t]{2}{*}{$P$} \\
\hline & & No. & $\%$ & & & & \\
\hline $17-26$ & 11393 & 10 & 0.088 & 0.3 & $0.17-0.7$ & 9.2 & $<0.001$ \\
\hline $27-36$ & 10657 & 19 & 0.18 & 1.1 & $0.5-1.8$ & 0.002 & 0.95 \\
\hline $37-46$ & 3052 & 15 & 0.49 & 3.6 & $1.9-6.8$ & 19.4 & $<0.001$ \\
\hline $47-56$ & 257 & 1 & 0.39 & 2.2 & $0.3-16.2$ & 0.6 & 0.41 \\
\hline$>56$ & 87 & 0 & 0 & \multicolumn{4}{|c|}{ Undefined } \\
\hline Total & 25446 & 45 & 0.18 & & & & \\
\hline
\end{tabular}

$\mathrm{OR}=$ Odds ratio $=$ Relative risk, $\mathrm{CI}=$ Confidence intervals, $\chi^{2}=$ Chi-square $=3.9$ or more significant, $P=$ Probability value $=0.05$ or less significant

\section{CONCLUSION}

In conclusion, this study has shown that prevalence of hepatitis B and C $(0.74 \%$ and $0.19 \%)$ has reduced in Yemen. Further educational programs should target both public and hospital personnel to increase awareness concerning these pathogens. It should be noted that the prevalence of hepatitis $\mathrm{B}$ and hepatitis $\mathrm{C}$ markers was lower among young donors than among older donors, hence; young people should be encouraged to donate blood to help ensure a long-term increase in the blood supply without jeopardizing safety. Finally, implementation of more sensitive tests (such as nucleic acid amplification testing [NAT] for $\mathrm{HIV}, \mathrm{HBV}$ and $\mathrm{HCV}$ ) that detect infection earlier (reduce the window period) will further decrease risks of transfusion-transmitted viral infections. Also, further study can be carried out performing NAT on seronegative blood donor samples to determine the risk of transfusion-transmitted.

\section{ACKNOWLEDGEMENTS}

Authors acknowledge the financial support of Hodeidah University, Hodeidah city, Yemen.

\section{AUTHOR'S CONTRIBUTION}

The manuscript was carried out, written, and approved in collaboration with all authors.

\section{CONFLICT OF INTEREST}

No conflict of interest associated with this work.

\section{REFERENCES}

1. Malekpour RMH. Use of ALLGIO probe assays for detection of $\mathrm{HBV}$ resistance to adefovir in patients with chronic hepatitis B, Kerman, Iran. Asian Pac J Cancer Prev 2012; 13:5463-7.

https://doi.org/10.1016/S2222-1808(16)61079-4

2. Soleimani FAS, Mollaei HR, Iranmanesh Z, Nikpour N, Motahar M. Evaluation of the frequency of precore/core mutation in patients with chronic hepatitis B, Kerman Southeast of Iran. Asian Pac J Trop Dis 2016; 6:603-7. https://doi.org/10.1016/S2222-1808(16)61093-9

3. WHO "Blood safety and availability Fact sheet 279". World Health Organization. Retrieved 21 January 2016.

4. WHO. Screening donated blood for transfusion-transmissible infections: recommendations (PDF). World Health Organization. 2009. ISBN 9789241547888.

5. FDA 2016 "Bacterial Detection Testing by Blood and Blood Collection Establishments and Transfusion Services to Enhance the Safety and Availability of Platelets for Transfusion". FDA U.S. Food and Drug Administration. Retrieved 21 January2016.

6. Al-Shamahy HA, IA Rabbad, A Al-Hababy. Hepatitis B virus serum markers among pregnant women in Sana'a, Yemen. - Ann Saudi Med 2003; 23:87-89. https://doi.org/10.5144/0256-4947.2003.87

7. Al- Nassiri K A, Raja'a Y A. Sana'a Pattern and risk factors of Hepatitis B among Yemeni Peoples in Sana'a. Middle East Jor WHO 2001; 7 (1/2). PMID: 12596964

8. Haidar NA. Prevalence of hepatitis B and hepatitis C in blood donors and high risk groups in Hajjah, Yemen Republic. Saudi Med J 2002; 23: 1090-1094. https://doi.org/10.1186/1471-2458-13-50

9. Altamimi W, Altraif I, El-Sheikh M, Alkshan A, Qasem L, Sohaibani M. Prevalence of HBsAg and anti-HCV in Saudi blood donors. Ann Saudi Med 1998; 18: 60-62. https://doi.org/10.5144/0256-4947.1998.60 
10. Saeed AA, Fairclough D, Al-Admawi AM, Bacchus R, Osoba A, Al-Rasheed A et al. Hepatitis C virus in Saudi Arabia - a preliminary survey. Saudi Med J 1990; 11: 331 332. https://doi.org/10.4103/1319-3767.103425

11. Sarkodie F, Adarkwa M, Adu-Sarkodie Y, Candotti D, Acheampong JW, Allain JP. Screening for viral markers in volunteer and replacement blood donors in West Africa. Vox Sang 2001; 80: 142-147. https://doi.org/10.1046/j.1423-0410.2001.00023.x

12. Othman BM, Monem FS. Prevalence of hepatitis C virus antibodies among intravenous drug abusers and prostitutes in Damascus, Syria. Saudi Med J 2002; 23: 393-395. PMID: 11953762

13. Dodd RY, Notari IV EP, Stramer SL. Current prevalence and incidence of infectious disease markers and estimated window-period risk in the American Red Cross blood donor population. Transfusion 2002; 42: 975-979.

14. Garcia Z, Taylor L, Ruano A, Pavon L, Ayerdis E, Luftig $\mathrm{RB}$, et al. Evaluation of a pooling method for routine anti$\mathrm{HCV}$ screening of blood donors to lower the cost burden on blood banks in countries under development. J Med Virol 1996; 49: 218-222.

https://doi.org/10.1002/(SICI)10969071(199607)49:3\%3C21 8::AID-JMV10\%3E3.0.CO;2-8

15. Caspari G, Gerlich WH, Beyer J, Schmitt H. Non-specific and specific anti-HCV results correlated to age, sex, transaminase, rhesus blood group and follow-up in blood donors. Arch Virol 1997; 142: 473-489. https://doi.org/10.1007/s007050050094

16. Mison LM, Young IF, O'Donoghue M, Cowley N, Thorlton $\mathrm{N}$, Hyland CA. Prevalence of hepatitis $\mathrm{C}$ virus and genotype distribution in an Australian volunteer blood donor population. Transfusion 1997; 37: 73-78. https://doi.org/10.1046/j.1537-2995.1997.37197176954.x

17. Wang JE. A study on the epidemiology of hepatitis C infection among blood donors in Singapore. J Pub Heal Med 1995; 17: 387-391.

https://doi.org/10.1093/oxfordjournals.pubmed.a043152

18. Mohsenizadeh M, Reza Mollaei H, and Ghaziizadeh $\mathrm{M}$. Seroepidemiological Study of Hepatitis B, C and HIV among Blood Donors in Kerman. Asian Pac J Cancer Prev 2017; 18(12): 3267-3272. https://doi.org/10.22034/APJCP.2017.18.12.3267

19. Moore A, Herrera G, Nyamongo J, Lackritz E, Granade T, Nahlen B, et al. Estimated risk of HIV transmission by blood transfusion in Kenya. Lancet 2001; 358: 657-660. https://doi.org/10.1016/S0140-6736(01)05783-X

20. Sentjens R, Sisay Y, Vrielink H, Kebede D, Ader HJ, Leckie $\mathrm{G}$, et al. Prevalence of and risk factors for HIV infection in blood donors and various population subgroups in Ethiopia. Epidemiol Infect 2002; 128: 221-228. https://doi.org/10.1017/s0950268801006604

21. World Bank. Prevalence of HIV (from The World Bank: Data). https://data. worldbank.org/ indicator/ sh.dyn.aids.zs 